\title{
INVESTIGATIONS ON CERTAIN BIOLOGICAL AND ECOLOGICAL PARAMETERS OF THE CEREAL LEAF MINER Syringopais temperatella LED. (LEPIDOPTERA: SCYTHRIDIDAE)
}

( Received: 18 . 9. 2006 )

By

\author{
F. A. Al-Zyoud
}

\section{Department of Plant Protection and IPM, Faculty of Agriculture, Mu'tah University, Karak, Jordan}

\begin{abstract}
The cereal leaf miner, Syringopais temperatella Led. (Lepidoptera: Scythrididae) has been a threatening pest on wheat over the last five years in Karak District-Jordan. The insect feeds on the plant foliage, soon turning its leaves into yellow and eventually leads to a sharp decline in production. Therefore, in order to establish control measures for this damaging pest, the current study was undertaken to investigate its biology (on wheat at $20 \pm 2^{\circ} \mathrm{C}$ ), parasitoid, preference for certain plant species and the degree of distribution in the Karak District.

The results showed that $S$. temperatella was able to develop on wheat and reach the adult stage. Mean total developmental period was 43.61 days. Total mortality was $74.70 \%$. Sex ratio (females: males) of S. temperatella was 1: 0.39. Total parasitism by Anilastus sp. Förster (Hymenoptera: Ichneumonidae) reached up to $49.45 \%$. Mean longevity of $11.36,12.09$ and 13.73 days for mated females, unmated females and males was recorded, respectively. The mean longevity of Anilastus sp. females with 15.64 days was significantly longer than that for males with 10.36 days. Maximum mean numbers of daily laid eggs by mated and unmated ones were 4.50 and 1.00 eggs/female, respectively. Mean total fecundity of mated females was $25.71 \mathrm{eggs} / \mathrm{female}$, being significantly higher than unmated ones with only 4.73 eggs/female.

The results also showed that $S$. temperatella preference among the different plant species tested was significantly greater for wild barely with a mean leaf area consumed of $2.04 \mathrm{~cm}^{2}$ as compared to barely with a mean of $0.72 \mathrm{~cm}^{2}$ or wheat with a mean of $0.37 \mathrm{~cm}^{2}$. Infestation by the cereal leaf miner is distributed at the central line extending from the northern to southern areas of Karak District.
\end{abstract}

Key words: biology, cereal leaf miner, distribution, parasitoid, preference, Syringopais temperatella.

\section{INTRODUCTION}

Wheat (Triticum durum) is one of the main crops primarily grown in the rain-fed areas, and to a lesser extent in the irrigated lands of Jordan. The area planted with wheat in Jordan is estimated at 427,000 dunums (dunum=1000 $\mathrm{m}^{2}$ ) producing a total of 43,800 tons, where $20 \%$ of this land space producing 12,100 tons located in Karak District (Statistical Year Book, 2002).

Several insects infesting wheat have been described worldwide. While most of these insects cause insignificant damage, some cause serious annual forage and yield reductions. However, as agriculture has expanded into areas not traditionally planted with wheat, and as agricultural practices and intensive pesticide usage eliminate the natural regulating forces that would normally check their populations, many insects have erupted into severe outbreaks wreaking near-total destruction to cereal crops (Harlan, 1992). Some insects that infest wheat in the field around the world belong to the insect orders; Thysanoptera, Hemiptera, Homoptera, Coleoptera, Diptera, Hymenoptera and Lepidoptera (Borror et al., 1989; Miller, 1991). The cereal leaf miner, Syringopais temperatella Led. (Scythrididae) is distributed in Jordan, Syria, Lebanon, Iraq, Iran, Turkey, Cyprus and Israel (Avidov and Harpaz, 1969). S. temperatella is considered one of the major insect pests that attack wheat in Iraq (Abu Yaman, 1971), Iran (Bahrami and Rajabi, 1993; Gholamreza, 2002), and Jordan (Mustafa, 2002). In addition, the pest is also known to attack barley (Al-Momany and Mustafa, 1990), wild grasses and Egyptian clover (Avidov and Harpaz, 1969).

In Jordan, S. temperatella is found in many districts, and the insect was initially considered a non-serious pest on wheat (Al-Momany and Mustafa, 1990). Nevertheless, since the 1990s, the pest is found in Karak District, and its population started to increase due to the annual rainfall 
reduction and the wrong agricultural practices. The insect was realized as a destructive pest only in 2001 (Mustafa, 2002). Wheat infestation by $S$. temperatella in Karak District has exceeded to $90 \%$ in some fields, and in others has ranged between $25 \%$ and $75 \%$, with a total infestation of 3,000 dunums in 2001 (Mustafa, 2002). The extent of the damage depends on the infestation level and rainfall. If the rainfall is regularly over the season, the infested plants regain strength and continue to develop in spite of the damage.

Many attempts have been made to control $S$. temperatella in Jordan, including deep plowing, crop rotation and intensive use of insecticides (Al-Momany and Mustafa, 1990; Mustafa, 2002). In the West Bank, insecticides were applied to control the pest, if the infestation increases over $10 \%$ per plant (Karzem, 1999). However, rapid knockdown, high target mortality and ease of application rapidly led to the adoption of pesticides to control cereal pests (Metcalfe, 1982; Osteen and Szmedra, 1989). But using of insecticides has been declining due to the realization that broad-spectrum insecticides not only kill target pest species, but also kill natural enemies of those pests (Gerson and Cohen, 1989; Debach and Rosen, 1991). Moreover, in Cyprus, S. temperatella has developed resistance to some insecticides (Georghiou and Lagunes-Tejeda, 1991). Therefore, it is crucial to find other control measures than insecticides to suppress the pest population.

Concomitantly, it is necessary to study the biology, phenology and ecology of the newly destructive pests to be able to help farmers to correct the timing of their control tactics. Furthermore, the cereal leaf miner on wheat has not been thoroughly investigated in Jordan. Moreover, the only control tactic currently used for the pest is chemical spraying; with no other control measures have been undertaken due to lack of adequate research. Therefore, for a better understanding of the biology and ecology of $S$. temperatella, and to develop management strategies to successfully suppress its population, biology, parasitoid, preference and distribution of the insect were undertaken in the present study.

\section{MATERIALS AND METHODS}

A stock culture of $S$. temperatella was maintained on wheat plants with individuals collected from open fields in Karak District (Karak city has Latitude of $31^{\circ} 11^{\prime \prime}$ and Longitude of $\left.35^{\circ} 42^{\prime \prime}\right)$. Rearing was kept in meshed cages of $50 \times 50 \times 50 \mathrm{~cm}$, and held under laboratory conditions at the Faculty of Agriculture, Mu'tah University. Wheat plants were grown in pots (12 $\mathrm{cm}$ in diameter and $12 \mathrm{~cm}$ in height) in a glasshouse. To maintain adequate host-plant supply, wheat plants were frequently replaced whenever needed. In order to obtain the appropriate stage of $S$. temperatella for experiments, many mated adult females were transferred to wheat leaf discs in large Petridishes (9 $\mathrm{cm}$ in diameter and $1.5 \mathrm{~cm}$ in height). The Petridishes were partially filled with $0.5 \mathrm{~cm}$ thick layer of wetted cotton pad, and the lid of each Petridish had a meshed hole to provide ventilation. The Petridishes were kept in a climatically controlled chamber at $20 \pm 2^{\circ} \mathrm{C}$, $60 \pm 10 \%$ relative humidity and a photoperiod of 12:12 (L: D) h. The Petridishes were checked daily, and the newly laid eggs were used directly or reared further until the required stage for each of the experiments was reached.

For the biology experiments of $S$. temperatella, the mated adult females were removed after one day from Petridishes. After that, the Petridishes were checked for the presence of eggs, and kept in an incubator under the same controlled conditions. In order to determine the developmental period of $S$. temperatella eggs, the laid eggs were investigated daily. The embryonic developmental period was recorded after hatching the larvae from the eggs. Newly hatched larvae were singly and gently transferred using a Camel's hairbrush into smaller Petridishes $(5 \mathrm{~cm}$ in diameter and $1 \mathrm{~cm}$ in height). These small Petridishes were also partially filled with $0.5 \mathrm{~cm}$ thick layer of wetted cotton pad, and each had a meshed hole in its lid to provide aeration. The Petridishes were provided with wheat leaf discs as the larvae feed. The progress of larval development was checked daily until they pupated. The larval instars were transferred at intervals of 1-2 days to new Petridishes provided by fresh wheat leaf discs. The pupation period was determined from the day the larvae entered into pupal stage to the day when the adult started emerging. Ninety-one replicates were used to calculate the developmental period in the experiment.

During the developmental experiment, mortality of eggs, larvae and pupae were recorded daily. The percentage of mortality in egg-, larvaland pupal stages as well as the total mortality were recorded. In order to exactly differentiate between living and dead individuals, several criteria were used, i.e., no larvae were hatched from dead eggs and failure of larvae to enter into pupation as well as no adults came out from dead pupae. Developmental experiment started with 360 replicates. To calculate the sex ratio of $S$. temperatella and its parasitoid, Anilastus sp., the 
emerged adults from the same experiment on development were separated according to insect species; the pest or the parasitoid, were sexed visually. The criteria used for sex differentiation of both insect species were the ovipositor of the female. The percentage of females and males as well as parasitism percentage was calculated.

For recording the longevity of $S$. temperatella and its parasitoid, newly emerged adults of both insect species ( $24 \mathrm{~h}$ maximum) were transferred to Petridishes. Each adults couple was separately kept in the Petridishes, and provided with a sugar solution. In another experiment, newly emerged unmated females of $S$. temperatella were kept singly in the Petridishes. All individuals in the Petridishes were incubated at the fore-mentioned experimental temperature until they died, and a sugar solution was provided whenever need. The longevity of the individuals was recorded. During the longevity experiment of $S$. temperatella, the first and last egg-laying days were recorded in order to determine the pre-oviposition, oviposition and post-oviposition periods of the pest females. In order to evaluate the fecundity of $S$. temperatella females during their oviposition period, the number of laid eggs was recorded daily, and removed immediately from the Petridishes during the experiment on longevity. Daily and total fecundity were determined, using a minimum of eleven replicates in the experiment.

\section{Host plant preference}

In order to determine the host plant species preferred by $S$. temperatella, wheat ( $T$. durum), barely (Hordeum valgare) and wild barely (Hordeum spontaneum) were tested. Several larvae of S. temperatella were kept in Petridishes, containing leaf discs of the three plant species for a period of one week. This step was performed in order to reduce the chance of larval adaptation to a particular plant species. Subsequently, large larvae (approximately $1 \mathrm{~cm}$ in length) were kept in small Petridishes as mentioned before. Oneleaf disc of $5-\mathrm{cm}^{2}$ area of each plant species was separately placed above the cotton pads in the Petridishes, each with only one S. temperatella larva for a period of two days. Hereafter, the larvae individuals were removed, and the mean leaf area consumed from the different plant species was measured. The experiments were conducted in a climatic chamber at the previously mentioned environmental conditions. Ten replicates were used for each plant species tested.

To determine the distribution of the cereal leaf minor in Karak District, frequent visits were made to the different areas. In addition, information was obtained with the cooperation with the main agricultural centers in Karak District, i.e., Al-Karak, Al-Qasr and Al-Mazar directly from the agricultural engineers in charge of monitoring the cereal leaf minor.

Statistical analysis was performed as onefactor analysis of variance. Significant differences among several means were determined utilizing LSD Test at $P<0.05$. T-Test was only used for comparisons between two means (Anonymous, 1996).

\subsection{Biology}

S. temperatella was able to develop on wheat plant as a host, and reach to adult stage at a temperature of $20^{\circ} \mathrm{C}$ (Figure $1 \mathrm{~A}$ ). The mean developmental periods of egg-, larval- and pupal stages were $12.93,19.20$ and 11.48 days, respectively. Mean total developmental period from egg deposition to adult emergence was 43.61 days. The mortality occurred during all of the developmental stages of $S$. temperatella (Figure 1B). During the egg stage, the highest mortality was recorded and reached $44.44 \%$. Within the larval stage, however, the mortality valued $34.50 \%$. The lowest mortality among all other immature stages was $30.53 \%$ during the pupal stage. Total mortality during development from egg to adult emergence was estimated at $74.70 \%$. Total mortality including parasitism of $12.52 \%$ was measured at $87.22 \%$ and the survival rate of S.temperatella was only $12.78 \%$.

Percentage of sexes and mean longevity period of females and males of $S$. temperatella and its parasitoid, Anilastus sp. are presented in Table (1). Female percentage of $S$. temperatella was higher than males, while for Anilastus sp. the female percentage was lower than males. Thus, the sex ratio (females: males) for $S$. temperatella and Anilastus sp. was 1: 0.39 and 1:1.25, respectively. The mean longevity of mated cereal leaf miner was 11.36 and 13.73 days for females and males, respectively.

While the longevity of unmated females was found to be 12.09 days. There were no significant differences in the mean longevity of males and females or between mated and unmated females. The mean longevity of Anilastus sp. females was significantly longer than males. The total parasitism by the parasitoid, Anilastus sp. reached up to $49.45 \%$.

Table (2) shows the mean periods of preoviposition, oviposition and post-oviposition of $S$. temperatella mated and unmated ones. The mean pre-oviposition period of mated females with 3.71 
Table (1): Percentage of sexes and mean longevity period of females and males of Syringopais temperatella and its parasitoid, Anilastus sp. on wheat leaf discs at $20 \pm 2^{\circ} \mathrm{C}$.

\begin{tabular}{|c|c|c|c|c|}
\hline & \multicolumn{2}{|c|}{ Syringopais temperatella } & \multicolumn{2}{|c|}{ Anilastus sp. } \\
\hline & Females & Males & Females & Males \\
\hline Percentage of sexes (\%) & 71.74 & 28.26 & 44.44 & 55.56 \\
\hline Mean longevity period (days \pm SE) & $11.36 \pm 1.66 \mathrm{a}$ & $13.73 \pm 1.27 \mathrm{a}$ & $15.64 \pm 2.17 \mathrm{~b}$ & $10.36 \pm 2.36 \mathrm{a}$ \\
\hline Min. & 24 & 21 & 29 & 26 \\
\hline
\end{tabular}

Means in row followed by different letters indicate significant differences between females and males within the same insect species at $\mathrm{P}<0.05$ (one-factor ANOVA).

days was significantly shorter than unmated ones with 7.82 days. Mean oviposition period of mated females was 7.43 days, being significantly longer than that for unmated ones with only 4.00 days. There were no significant differences in the mean post-oviposition period of mated and unmated females. The mean daily and total number of laid eggs by $S$. temperatella mated and unmated females during the oviposition period are presented in Figure (1C). Mean number of daily number of laid eggs by $S$. temperatella (Figure 1C). Mean total number of laid eggs by mated females of $25.71 \mathrm{eggs} / \mathrm{female}$ was significantly greater than other for unmated ones with only 4.73 eggs/female.

\subsection{Preference}

The mean leaf area $\left(\mathrm{cm}^{2}\right)$ consumed by $S$. temperatella larvae by feeding upon different plant species in a feeding period of two days is summarized in Figure (1D). The results indicate

Table (2): Mean periods of pre-oviposition, oviposition and post-oviposition of Syringopais temperatella by feeding on wheat leaf discs at $20 \pm 2^{\circ} \mathrm{C}$.

\begin{tabular}{|l|c|c|c|c|c|c|c|c|c|}
\hline & \multicolumn{1}{|c|}{ Period (days) } \\
\cline { 2 - 11 } & \multicolumn{3}{|c|}{ Pre-oviposition } & \multicolumn{3}{c|}{ Oviposition } & \multicolumn{3}{c|}{ Post-oviposition } \\
\cline { 2 - 11 } & mean \pm SE & min. & max. & mean \pm SE & min. & max. & mean \pm SE & min. & max. \\
\hline Mated females & $3.71 \pm 0.57 \mathrm{a}$ & 2 & 6 & $7.43 \pm 1.70 \mathrm{~b}$ & 4 & 16 & $2.86 \pm 1.08 \mathrm{a}$ & 0 & 6 \\
\hline Unmated females & $7.82 \pm 0.76 \mathrm{~b}$ & 4 & 12 & $4.00 \pm 0.97 \mathrm{a}$ & 1 & 12 & $3.09 \pm 0.87 \mathrm{a}$ & 0 & 8 \\
\hline
\end{tabular}

Means in columns followed by different letters indicate significant differences between males and unmated females within the same type of period at $\mathrm{P}<0.05$ (one-factor ANOVA).

laid eggs varied according to mated and unmated females. The mated females began oviposition 3 days after emergence, with a daily fecundity mean of 2.00 eggs/female on the $3^{\text {rd }}$ day. Fecundity mean decreased afterwards, and then increased sharply to reach a peak of 4.50 eggs/female on the $9^{\text {th }}$ day. Mean daily number of laid eggs fluctuated until the $11^{\text {th }}$ day, then it decreased sharply until recorded zero on the $13^{\text {th }}$ day. The mean daily fecundity increased hereafter, and reached to 2.33 eggs/female on the $16^{\text {th }}$ day. After that, the mean daily number of laid eggs began to fluctuate until it approached zero on the $19^{\text {th }}$ day. In contrast, the unmated females started laying eggs on the $5^{\text {th }}$ day after their emergence, by a mean of 0.18 eggs/female. Mean daily fecundity increased, and then fluctuated hereafter and reached a maximum of $1.00 \mathrm{egg} / \mathrm{female}$ on the $10^{\text {th }}$ day. After that, the number of daily laid eggs began to fluctuate until the $13^{\text {th }}$ day. Starting from the $13^{\text {th }}$ day, the number of daily laid eggs began to decrease gradually until no eggs were laid after the $17^{\text {th }}$ day. The case whether females are mated or unmated had significantly influenced the total that among the three plant species tested in the experiment, the cereal leaf miner preferred significantly wild barely with a mean of $2.04 \mathrm{~cm}^{2}$ to barely with a mean of $0.72 \mathrm{~cm}^{2}$ and wheat with a mean of $0.37 \mathrm{~cm}^{2}$.

\subsection{Distribution}

The distribution of the cereal leaf miner in Karak District is illustrated in Figure (2). It is clearly shown that the infestation by the pest is distributed at the central line extending from the northern to southern sites of the District. The infested areas by the pest in 2006 season from the north to the south are as follows: Gada, Majdoleen, Shahtour, Al-Qasr, Al-Rabba, Bateer, Al-Rawda, Rakin, Al-Wasia, Al-Haweh, Mutah, Al-Mazar, Al-Hadaba, Al-Amka, Majra, AlHuseiniya, Sarareh and Dhat Ras.

\section{DISCUSSION}

The cereal leaf miner is one of the major insect pests that attack wheat in Jordan. In Karak District of Jordan, S. temperatella became a destructive pest since 2001 (Mustafa, 2002). Insect feeds on the plant foliage, soon turning its leaves' color into 
yellow, leading to a sharp decline in production. However, the current results indicated that $S$. temperatella was able to develop on wheat as a host plant. Mean developmental periods of egg-, larvaland pupal stages were 12.93, 19.20 and 11.48 days, respectively. Avidov and Harpaz (1969) mentioned that the egg development lasted for 8-17 days, while pupal development has taken 14 days, which is in the same trends of the current results. In the present research, the mortality percentage was high. It might be due to parasitism, temperature and $\mathrm{RH}$ factors as well as a fact that wheat leaves are harder and thicker than other cereal crops such as barely. Total parasitism by Anilastus sp. was reached up to $49.45 \%$. However, no previous studies have been conducted on the mortality and parasitism percentages except that Bodenheimer (1930) reported that parasitoids of the Ichneumonid genus Anilastus were bred from bodies of $S$. temperatella larvae. It is to be noted that the parasitism percentage found in the present study was high enough to make a sufficient reduction in the pest population. Therefore, almost care should be taken not to disturb the agro-ecosystem in order to give the chance for this parasitoid to build up its population successfully.

The current work indicated that the mean longevity of $S$. temperatella was 11.36 and 13.73 days for females and males, respectively. In this regards, Avidov and Harpaz (1969) stated that $S$. temperatella adults lived for 2-3 weeks, and Mustafa (2002) listed longevity of 2 weeks. In general, the high variability in temperatures, plant species and even plant species cultivars used in other studies might explain the discrepancy to our current findings.

The mean pre-oviposition period of mated females was significantly shorter than that of unmated ones in the present work. It is possible that the mating has accelerated egg laying. However, Avidov and Harpaz (1969) estimated the preoviposition period of 3-7 days, while Mustafa (2002) stated that the pre-oviposion period was 1 week, in agreement with results of the current experiment. The mean total number of laid eggs by mated females of $S$. temperatella was 25.71 eggs/female. However, a single female laid 50-125 eggs (Avidov and Harpaz, 1969), and a mean of 57 eggs/female was stated by Mustafa (2002). Variations between the present and prior studies might be due, in addition to the different temperatures used in the different studies, to the prey's host plant species or even cultivar. Also, it is to be mentioned that the insect has reproduced parthenogentically.
The current results indicated that the cereal leaf miner preferred significantly wild barely to barely and wheat. It might be due to the fact that wheat and barely leaves are harder and thicker than that of wild barley. Therefore, the larvae could gnaw mines easier and faster in wild barely leaves rather than wheat and barely. Also, such a preference might be due to other physical and chemical factors in the wild barley, which are preferable by the pest larvae.

It is clear that the infestation by the pest is distributed at the central line extending from the northern to southern of Karak District. In the present study, eighteen different areas were infested by the pest in 2006, comparing with only three areas in 2001 namely; Al-Mazar, Al-Qasr and Al-Wasia (Mustafa, 2002). This proved that the infestation is expanded yearly from one hand, and from the other hand the pest hits fields that have been previously infested, since the areas infested in 2001 were also infested in 2006, which is in agreement with a conclusion made by Karzem (1999).It is noted that the infestation has distributed in the areas located at the central line from the northern to southern of the district, and these areas are considered as higher areas in the District, and have a moderate temperature, which might be preferable by the pest. In contrast, the east areas of the District are consisting of semidesert areas and many Wadies (very low areas) such as in Al-Nokaleh, Al-Ramleh and Al-Petra. In the west areas, there are the Dead Sea and many Wadies such as Al-Shakek, Asal and Jedareh as well as many other very low areas (Khors) such as Al-Mazreh, Al-Henawi and Namireh. From the north, there is Wadi Al-Mujib, which is a very big Wadi, while from the south part, there are Wadi Al-Hasa and Wadi AlSharma. However, the east, west, north and south areas of Karak District are characterized by a high temperature, which might be unprefereble by the pest. Therefore, the pest sensitivity to high temperatures explains their distribution in the middle areas of the District, which agrees with results obtained by Karzem (1999).

According to the field observations, the larvae started feeding on wheat leaves on early February and the moths started appearing in late April. In Jordan, Mustafa (2002) reported that the larvae penetrate the leaves in January and February in 2001. In Israel, Avidov and Harpaz (1969) mentioned that in January and early February, the larvae emerge from the ground and penetrate the leaf mesophyll, and the moths first appear in March and are abundant by April. 


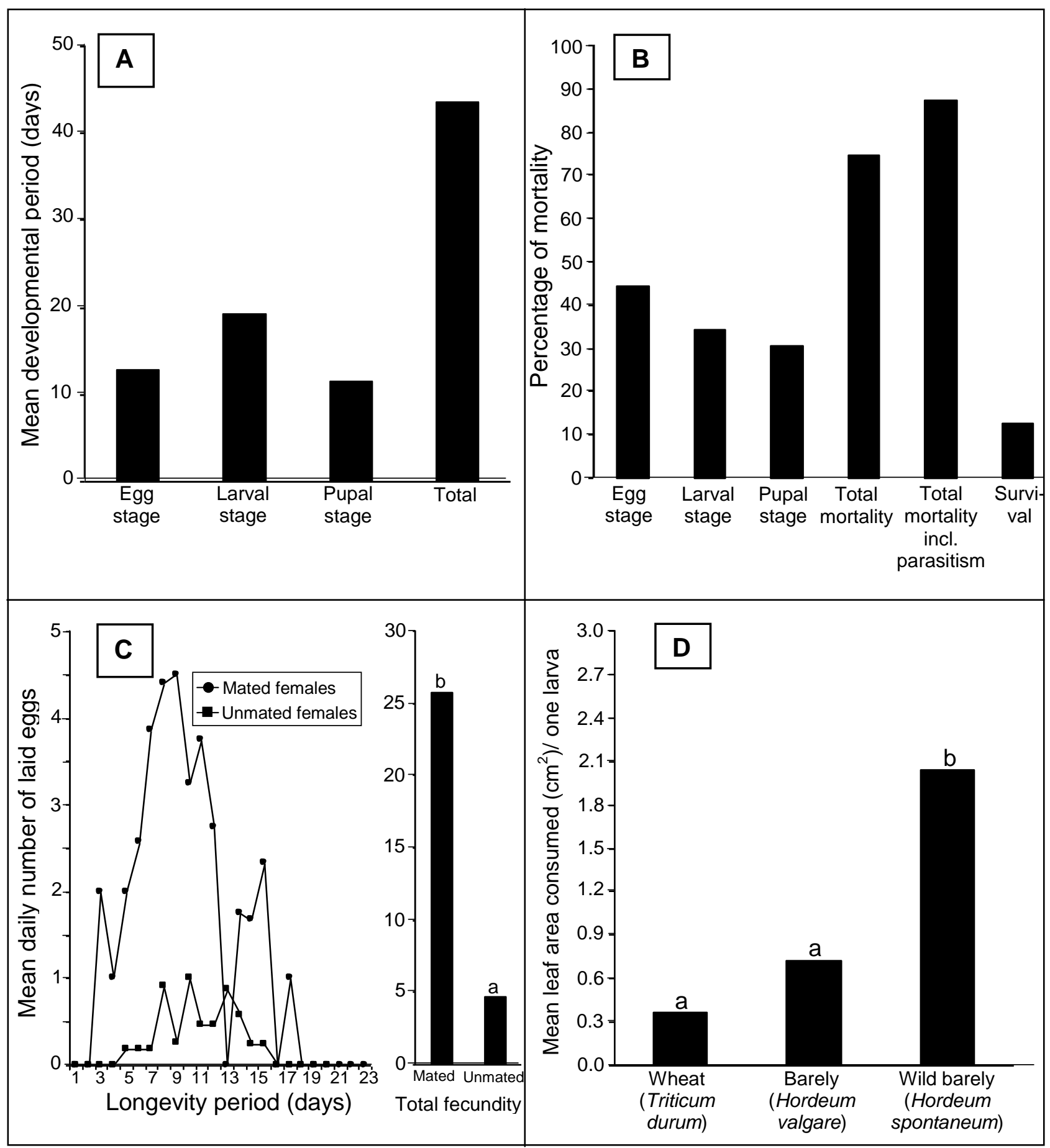

Fig (1): Certain biological parameters of $S$. temperatella under controlled conditions of $20 \pm 2^{\circ} \mathrm{C}$ \&60 $\pm 10 \%$ R.H

a. Mean developmental period of immature stages.

b. Mortality of immature stages.

c. Mean daily and total egg laid number (Mated \& unmated)

d. Mean leaf area $\left(\mathrm{cm}^{2}\right)$ consumed by one larva. 


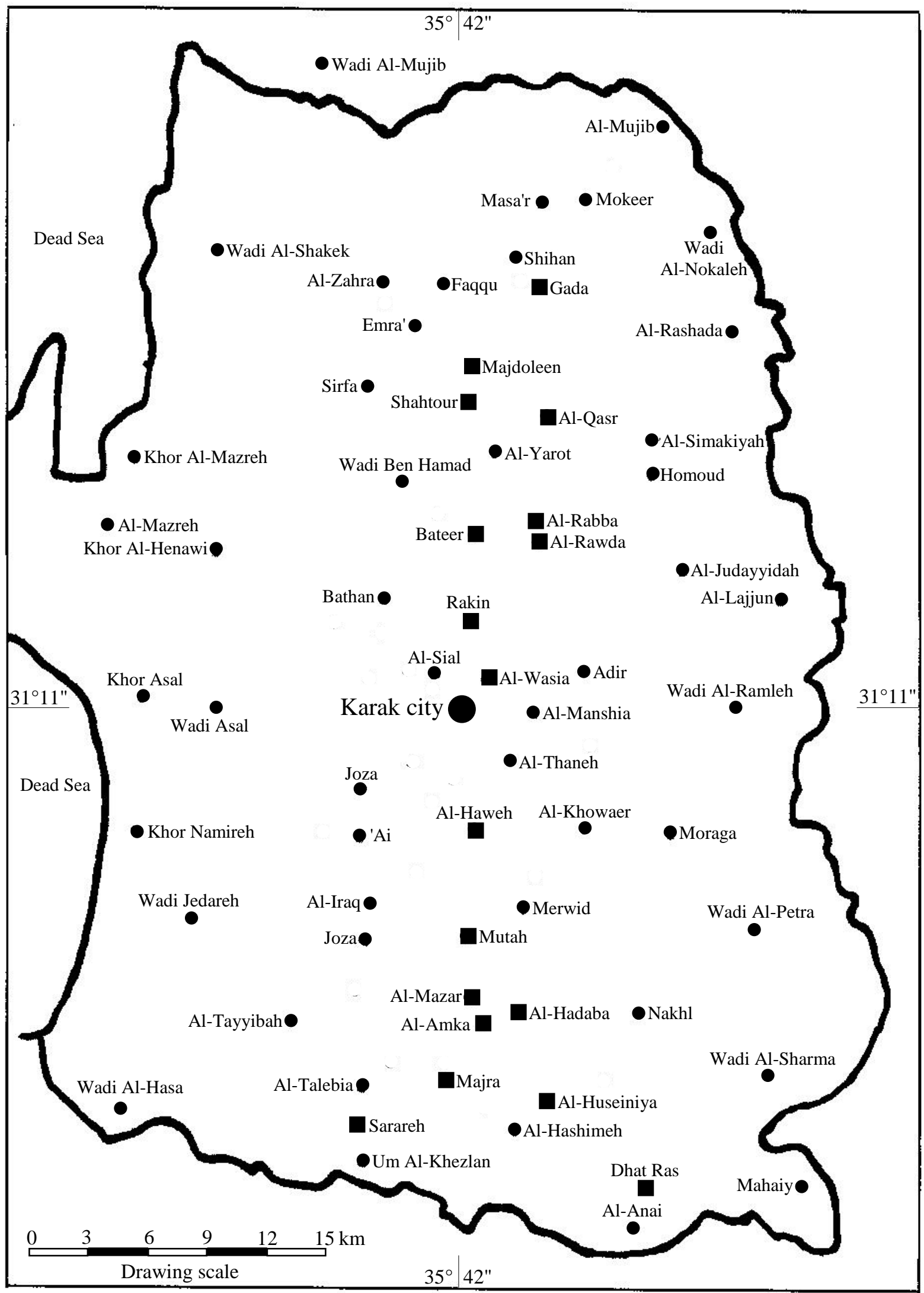

Fig. (2): Distribution of the cereal leaf minor in Karak District, 2006. The areas signed with black square symbol (๘) are infested by Syringopais temperatella. 
February in 2001. In Israel, Avidov and Harpaz (1969) mentioned that in January and early February, the larvae emerge from the ground and penetrate the leaf mesophyll, and the moths first appear in March and are abundant by April. While in the West Bank, Karzem (1999) mentioned that the larvae are abundant in December to February. These results are in agreement with the results of the current study.

In conclusion, Jordan has begun to address the cereal leaf miner pest problem, although there is a scarcity of research in this area. The current study provides basic information on some biological and ecological parameters of the pest. However, it appears that future researches should be focused on the parasitoid, Anilastus sp., since parasitism reached up to $50 \%$; and on the resistance of cultivated, land races and wild cultivars of wheat to the pest. These future studies together with the present results are expected to form the foundation of IPM program for $S$. temperatella in Jordan.

\section{REFERENCES}

Abu-Yaman I.K. (1971). Control of the wheat leaf miner Syringopais temperatella Led. in Iraq. J. of Plant Diseases and Protection, 68(3):322-326.

Al-Momany A. and Mustafa T. (1990). Garden and House Pests. Al-Dar Al-Arabia for Publishing and Distribution, Cairo, Egypt, $360 \mathrm{pp}$.

Anonymous. (1996). Reference Manual of The Statistics Program for Windows Winstat. Kalmia Company Inc, Cambridge, MA,267 pp.

Avidov Z. and Harpaz I. (1969). Plant Pests of Israel. Jerusalem, Israel Universities Press, $378 \mathrm{pp}$.

Bahrami N. and Rajabi G.H. (1993). Primary investigation on biology of Syingopais temperatella Led. in Kermanshah province. $11^{\text {th }}$ Iranian Plant Protection Congress, Iran p. 6.

Bodenheimer F.S. (1930). Die Schädlings fauna Palästinas. Monograpgin zur angewandten Entomologie, Paul Parey, Berlin No. 10.
Borror D.J., Triplehorn C.A. and Johnson N.F. (1989). An Introduction to the Study of Insects. $6^{\text {th }}$ edition, Saunders College Publishing, Philadelphia, USA, 875 pp.

Debach P. and Rosen D. (1991). Biological Control by Natural Enemies. Cambridge University Press, Cambridge, UK, 440 pp.

Georghiou G.P. and Lagunes-Tejeda A. (1991). The occurrence of resistance to pesticides in arthropods: an index of cases reported through 1989, FAO, Rome, Italy, 11-22.

Gerson U. and Cohen E. (1989). Resurgence of spider mites (Acari: Tetranychidae) induced by synthetic pyrethroids. Exp. Appl. Acarol., 6:29-46.

Gholamreza R. (2002). Biology of cereal leaf miner Syringopais temperatella Led. in cereal post harvest period in Khuzestan province. $15^{\text {th }}$ Iranian Plant Protection Congress, Iran.

Harlan J.R. (1992). Crops and Man. $2^{\text {nd }}$ edition, American Society of Agronomy, Madison, Wisconsin, USA, 284 pp.

Karzem G. (1999). Chemical Control and Dirty War: An Introduction to the Alternatives. Work Center for Improvement, Ram Allah, West Bank.

Metcalfe R.L. (1982). Insecticides in Pest Management. In: Metcalfe R.L. and Luckmann W.H. (Eds), Introduction to Insect Pest Management, $2^{\text {nd }}$ edition, John Wiley and Sons, New York, USA, 217-277.

Miller R.H. (1991). Insect Pests of Wheat and Barley in West Asia and North Africa. Technical Manual, ICARDA, Aleppo, Syria, $136 \mathrm{pp}$.

Mustafa T. (2002). Cereal leaf miner: a destructive pest on wheat in Karak District. J. Agric. Eng. 17-19.

Osteen C.D. and Szmedra P.I. (1989). Agricultural Pesticide Use Trends and Policy Issues. Agricultural Economic Report No. 622, Washington DC, USDA, USA.

Statistical Year Book (2002). Department of Statistics, Amman, the Hashemite Kingdom of Jordan.

\section{Syringopais temperatella LED. دراسة بعض الخصائص الحيوية والبيئية لصانعة أنفاق أولق الحبوب (LEPIDOPTERA: SCYTHRIDIDAE)}

$$
\begin{aligned}
& \text { فراس احمد الزيود } \\
& \text { قسم وقاية النبات و المكافحة المتكاملة ـ كلية الزر اعة ـ جامعة مؤتة ـالكرك ـ الأردن }
\end{aligned}
$$




\section{ملخص}

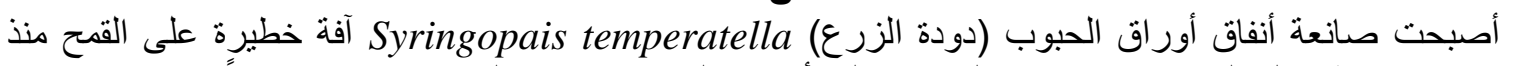

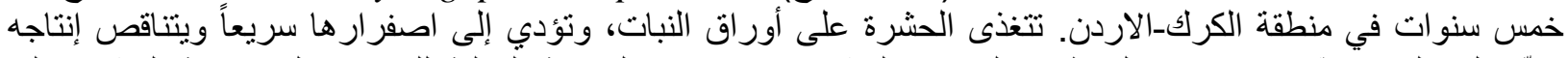

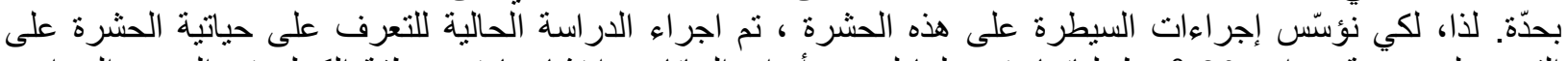

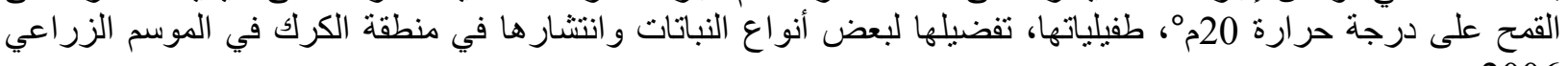

أنثارت النتائج إلى أن صانعة أنفاق أوراق الحبوب قد أكملت نطورها على نبات القمح وكان معدل التطور الكلي

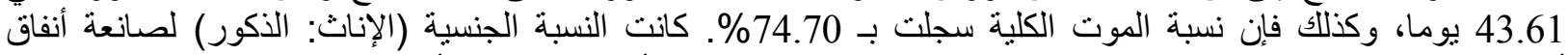

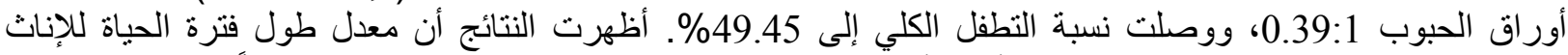

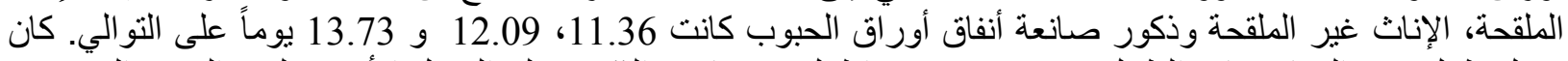

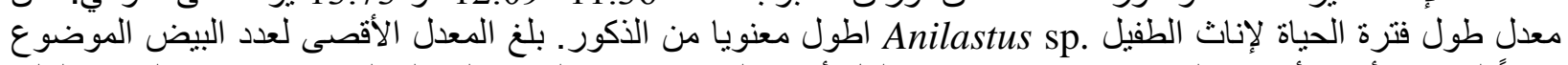

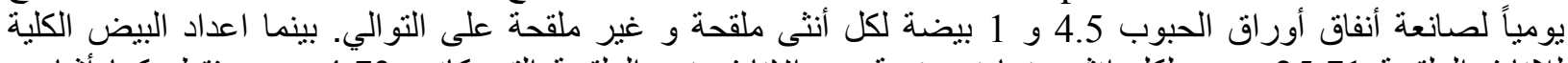

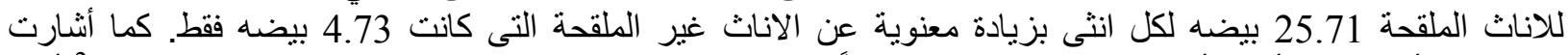

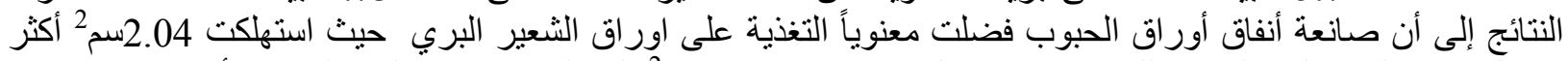

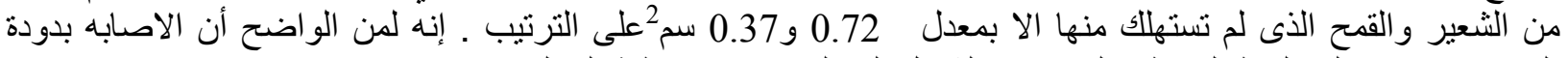

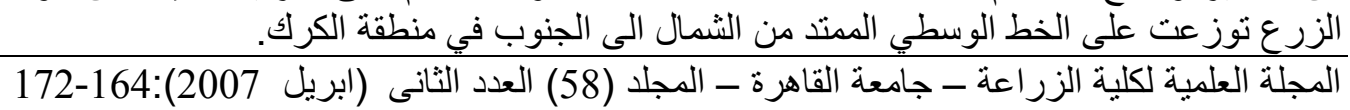

